\title{
Banana liqueur made with yacon syrup: evaluation of stability during maturation
}

\section{Licor de banana elaborado com xarope de yacon: avaliação da estabilidade durante a maturação}

\author{
Leandro Levate Macedo ${ }^{1 *}\left(\mathbb{0}\right.$, Wallaf Costa Vimercati ${ }^{1} \odot$, Cintia da Silva Araújo ${ }^{1}$, \\ Antonio Manoel Maradini Filho', Sérgio Henriques Saraiva ${ }^{1}$, \\ Luciano José Quintão Teixeira ${ }^{1}$ \\ ${ }^{1}$ Universidade Federal do Espírito Santo (UFES), Departamento de Engenharia de Alimentos, Alegre/ES - Brasil
}

${ }^{*}$ Corresponding Author: Leandro Levate Macedo, Universidade Federal do Espírito Santo (UFES), Centro de Ciências Agrárias e Engenharias, Departamento de Engenharia de Alimentos, Alto Universitário, s/n, CEP: 29500000, Alegre/ES - Brasil, e-mail: leandrolevate@hotmail.com

Cite as: Macedo, L. L., Vimercati, W. C., Araújo, C. S., Maradini Filho, A. M., Saraiva, S. H., \& Teixeira, L. J. Q. (2021). Banana liqueur made with yacon syrup: evaluation of stability during maturation. Brazilian Journal of Food Technology, 24, e2020031. https://doi.org/10.1590/1981-6723.03120

\begin{abstract}
The aim of this work was to evaluate the stability during maturation of banana liqueurs made with yacon syrup and sucrose. Thus, $20^{\circ} \mathrm{GL}$ and $30^{\circ} \mathrm{Brix}$ liqueurs were produced using yacon and sucrose syrups at concentrations of 42.8 and $45.0^{\circ} \mathrm{Brix}$. The liqueurs were subjected to two procedures as following: heat treatment at $70^{\circ} \mathrm{C}$ for $20 \mathrm{~min}$ (tranchage), followed by storage at room temperature for 10 days (T42-T and T45-T); no heat treatment and storage at $50^{\circ} \mathrm{C}$ for 10 days (T42-50 and T45-50). The color and turbidity of liqueurs were evaluated daily within 10 days of storage. The alcohol content was evaluated every 2 days. The total color difference $(\Delta \mathrm{E})$ was calculated in relation to color at time zero for each treatment. The T42-50 treatment had the lowest turbidity at the end of maturation. The T45-T treatment presented the lowest $\Delta E$ value at the end of maturation. The alcohol contents regarding the liqueurs were the same as those contents after elaboration as well as did not change over the maturation time for all treatments.
\end{abstract}

Keywords: Liqueur; Musa spp.; Smallanthus sonchifolius; Turbidity; Alcohol content; Color difference.

\section{Resumo}

O objetivo deste trabalho foi avaliar a estabilidade, durante a maturação, de licores de banana elaborados com xarope de yacon e sacarose. Para isso, foram produzidos licores com $20^{\circ} \mathrm{GL}$ e $30^{\circ} \mathrm{Brix}$, a partir de xaropes de yacon e sacarose nas concentrações de 42,8 e $45,0^{\circ}$ Brix. Os licores foram submetidos a dois procedimentos: tratamento térmico a 70 ${ }^{\circ} \mathrm{C}$ por 20 minutos (tranchage), seguido de armazenamento a temperatura ambiente por dez dias (T42-T e T45-T), e armazenamento dos licores a $50^{\circ} \mathrm{C}$ por dez dias (T42-50 e T45-50), sem aplicação de tratamento térmico. A cor e a turbidez dos licores foram avaliadas diariamente, durante os dez dias de armazenamento. $\mathrm{O}$ teor alcoólico foi avaliado de dois em dois dias. A diferença total de cor $(\Delta \mathrm{E})$ foi calculada em relação a cor no tempo zero, para cada tratamento. O tratamento T42-50 apresentou a menor turbidez ao final da maturação. O tratamento T45-T apresentou o menor valor de $\Delta \mathrm{E}$ ao final da maturação. Os teores alcoólicos dos licores apresentaram-se iguais entre si logo após a elaboração e não sofreram alterações ao longo do tempo de maturação, para todos os tratamentos.

Palavras-chave: Licor; Musa spp.; Smallanthus sonchifolius; Turbidez; Teor alcoólico; Diferença de cor. 


\section{Introduction}

Liqueur is an alcoholic beverage made by mixing water, alcohol, sugar, and flavoring, with an alcohol content of $15 \%$ to $54 \%$ and sugar content of more than $30 \%$. Liqueur production is a process that can be carried out by hand, since it requires only simple technologies, being a good way to use raw material, such as fruits, produced in small rural properties. In addition to being able to be stored at room temperature, the liqueur has a long shelf life and shows a good sensory acceptance, which favors the commercialization of the product and the increase in family income (Teixeira et al., 2005; Barros et al., 2008; Viera et al., 2010; Oliveira \& Santos, 2011).

The addition of ingredients can be used in the liqueur elaboration process in order to add functional, nutritional, technological or sensory properties to the product, with the view of meeting the growing consumer demand for foods with different characteristics. In this context, the banana (Musa spp.) is commonly used to add, mainly, sensory properties to the products, as observed by Teixeira et al. (2007), when evaluating sensory acceptance of banana liqueur. In addition, bananas have high fiber content and the presence of some essential vitamins and minerals, such as vitamin C, potassium, magnesium, phosphorus and calcium (Food and Agriculture Organization of the United Nations, 2019). In addition to fruits, other foods can be added to the liqueur elaboration process.

The yacon (Smallanthus sonchifolius Poepp. \& Endl.) has been used as a promisor ingredient in meat products (Contado et al., 2015), bread products (Padilha et al., 2010; Rocha et al., 2015) and dairy products (Moreira Junior et al., 2018). The interest in the use of yacon in the elaboration of food products is due to its richness in fructooligosaccharides (FOS), which have prebiotic functions in the human body, reducing the risk of developing gastrointestinal disorders, cancer, diabetes, and cardiovascular diseases (Caetano et al., 2016; Almeida Paula et al., 2015; Macedo et al., 2020a). Despite all its beneficial effects, the yacon has not yet been studied as an ingredient for making liqueurs.

The last step of the liqueur manufacturing process is maturation, also known as aging or rest. This step influences the sensory properties of the product, especially the strong alcoholic taste of young liqueur. After maturation, the liqueur has a pleasant taste as a result of several reactions during aging, which improve some desirable characteristics and eliminate the undesirable ones (Ma et al., 2014). Various treatments have been adopted in scientific studies. Viera et al. (2010) adopted a 30-day time at room temperature for camu-camu liqueur. Teixeira et al. $(2007,2012)$ and Passos et al. (2013) used a maturation time of 60 days at room temperature. Almeida et al. (2012) and Bragança (2013) adopted a 90-day time at room temperature. In their investigation, Nogueira \& Venturini Filho (2005) and Oliveira et al. (2015) adopted accelerated aging using a temperature of $60{ }^{\circ} \mathrm{C}$ for 48 and 2 hours, respectively.

Therefore, the aim of this study was to prepare banana liqueur with syrup of yacon and sucrose and to evaluate its stability during storage using accelerated maturation methods.

\section{Material and methods}

The experimental steps are shown in Figure 1. The experiment was conducted in three repetitions.

\subsection{Preparation of bananas}

The banana (about $30 \mathrm{~kg}$ ), of the silver variety, was acquired in the commerce of the municipality of Alegre-ES. The banana bunches were washed in running water and then, they were removed from bunches by hand. Bananas at the degree of ripeness four (4) were selected, according to the scale established by Programa Brasileiro para a Modernização da Horticultura \& Produção Integrada de Frutas (2006).

The bananas were manually peeled and cut transversely into $5 \mathrm{~mm}$ slice thickness, with the aid of a manual vegetable slicer. 


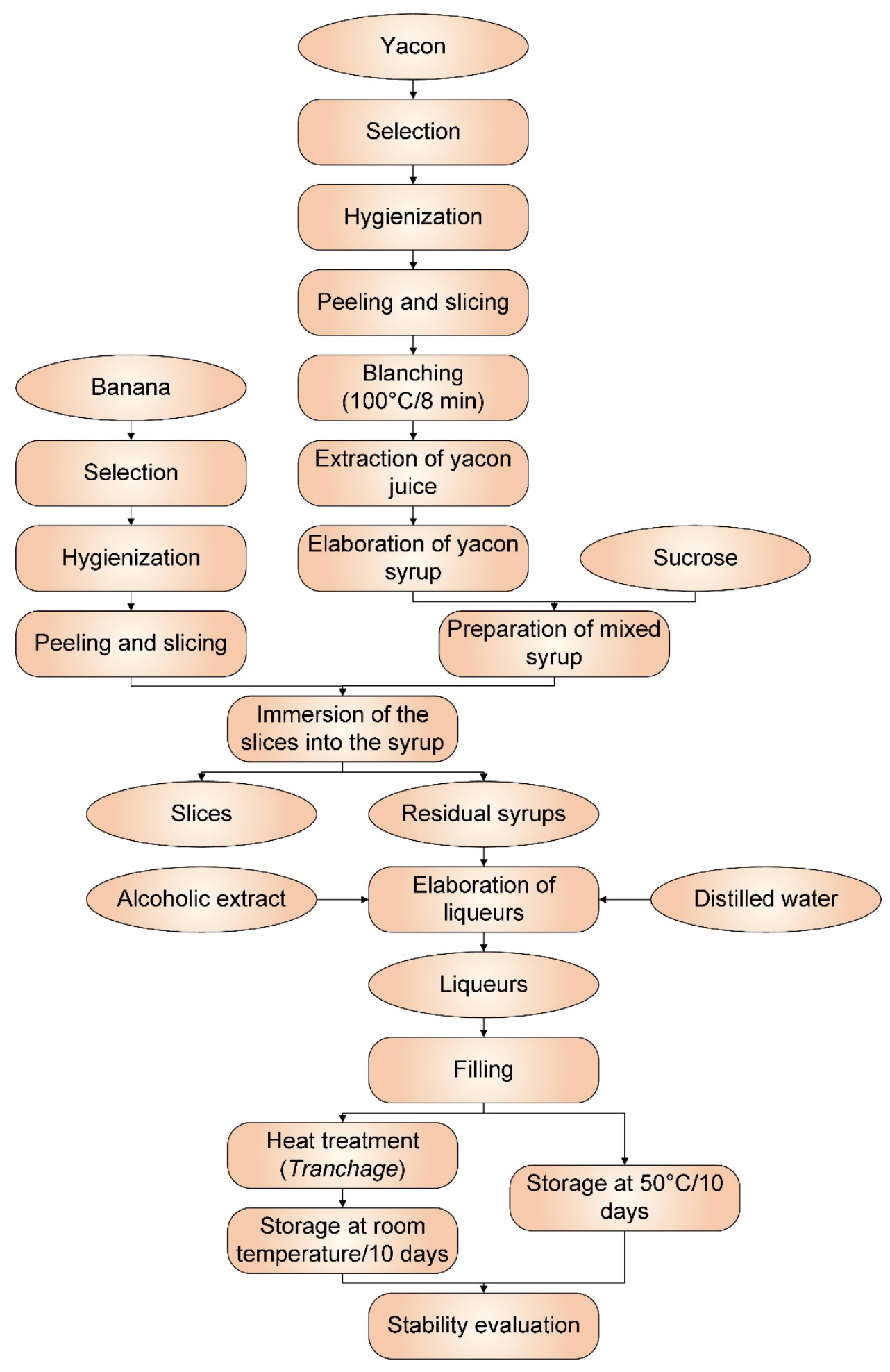

Figure 1. Flowchart of the experimental procedure.

\subsection{Preparation of mixed syrup}

The yacon (about $200 \mathrm{~kg}$ ) was purchased in the municipal market of Alegre, in the state of Espírito Santo (ES). The roots were washed with running water and sanitized by immersion in a $200 \mathrm{ppm}$ free residual chlorine solution for $10 \mathrm{~min}$, followed by rinsing. The roots were selected for integrity. The skin was removed with the aid of a fixed blade vegetable peeler. 
The peeled roots were cut in the transverse direction, originating $5 \mathrm{~mm}$ slice thickness, and subjected to thermal blanching by immersion water at $100^{\circ} \mathrm{C}$ for $8 \mathrm{~min}$, in a proportion of $1: 10(\mathrm{~m} / \mathrm{v})$, followed by an ice bath (Macedo et al., 2019).

The roots were inserted in a centrifuge (Mondial, model NCF-01, China). The extracted juice passed through a sieve inside the centrifuge, where solid extraction residues were removed.

The yacon juice was placed in an aluminum container and heated with automatic stirring to produce the yacon syrup. This process was interrupted when the syrup had a soluble solids content of $30^{\circ} \mathrm{Brix}$, verified with the aid of a digital bench refractometer, Hanna, HI 96801 . Above $30^{\circ}$ Brix, the viscosity of the syrup was significantly high and would make it difficult to continue the experiment.

Sucrose was added to the yacon syrup, producing the mixed syrups with 42.8 and $45.0^{\circ}$ Brix, based on a previous study.

The banana slices were immersed into the mixed syrups in a 1:11 (m/v) ratio, for five (5) hours, in order to transfer the aromatic compounds from the fruit into the mixed syrup. Afterward, the slices were removed, obtaining residual syrups.

\subsection{Alcoholic extract}

The alcoholic extract was prepared by the infusion of fresh banana slices in cereal alcohol $\left(95^{\circ} \mathrm{GL}\right)$ for 21 days, in the proportion of 2: $5(\mathrm{~m} / \mathrm{v})$, followed by filtration with filter paper (Teixeira et al., 2005). At the end of the process, the alcoholic extract showed $64.26^{\circ} \mathrm{GL}$.

\subsection{Elaboration of liqueurs}

The liqueurs were made by mixing residual syrups, banana alcoholic extract and distilled water, to present $20{ }^{\circ} \mathrm{GL}$ and $30 \%(\mathrm{w} / \mathrm{v})$ of sugar (Teixeira et al., 2007). The added quantities of residual syrup, alcoholic extract and distilled water for the preparation of the liqueurs were calculated according to Equations 1, 2 and 3, respectively.

$$
\begin{aligned}
& X=\frac{L^{*} S S_{L}}{S S_{X}} \\
& E=\frac{T A_{L} * L}{T A_{E}} \\
& W=L-X-E
\end{aligned}
$$

Where, $\mathrm{X}, \mathrm{E}$, and $\mathrm{W}$ are the quantities in $\mathrm{mL}$ of residual syrup, alcoholic extract, and distilled water, respectively; $\mathrm{L}$ is the quantity of liqueur, in $\mathrm{mL} ; \mathrm{SS}_{\mathrm{L}}$ is the Soluble Solids Content (SSC) of the liqueur, in ${ }^{\circ} \mathrm{Brix}$; $\mathrm{SS}_{\mathrm{X}}$ is the $\mathrm{SSC}$ of the residual syrup, in ${ }^{\circ} \mathrm{Brix}$; $\mathrm{TA}_{\mathrm{L}}$ is the alcoholic strength of the liqueur, in ${ }^{\circ} \mathrm{GL}$; $\mathrm{TA}_{\mathrm{E}}$ is the alcohol content of the alcoholic extract, in ${ }^{\circ} \mathrm{GL}$.

The liqueurs were filled in $600 \mathrm{~mL}$ amber glass bottles (about $3 \mathrm{~mm}$ thick).

\subsection{Liqueur treatments}

Liqueurs with 42.8 and $45.0^{\circ}$ Brix were subjected to two different procedures. One of the procedures was the heat treatment, called "tranchage", in which the bottles were placed in a water bath at $70{ }^{\circ} \mathrm{C}$ for $20 \mathrm{~min}$, followed by cooling in an ice bath, until reaching room temperature (Reventos, 1971; Teixeira et al., 2007). The bottles were subsequently kept at room temperature for 10 days. The second procedure consisted of keeping the liqueurs at $50{ }^{\circ} \mathrm{C}$, in an oven (Tecnal, TE-394/2-MP, São Paulo, Brazil) during the 10 days of storage. 
The codes of the treatments according to the concentration of total soluble solids of the syrup used in the preparation of the liqueurs and of the procedures after the elaboration are presented in Table 1.

Table 1. Liqueur treatments.

\begin{tabular}{ccc}
\hline Treatments & Syrup concentration $\left({ }^{\circ}\right.$ Brix) & Maturation procedure \\
\hline $\mathrm{T} 42-\mathrm{T}$ & 42.8 & Tranchage \\
\hline $\mathrm{T} 45-\mathrm{T}$ & 45.0 & Tranchage \\
\hline $\mathrm{T} 42-50$ & 42.8 & $50{ }^{\circ} \mathrm{C}$ \\
\hline $\mathrm{T} 45-50$ & 45.0 & $50{ }^{\circ} \mathrm{C}$ \\
\hline
\end{tabular}

Tranchage: $70^{\circ} \mathrm{C} / 20 \mathrm{~min}$ and then storage at room temperature; $50^{\circ} \mathrm{C}$ : storage temperature for 10 days.

\subsection{Stability evaluation}

The liqueurs were subjected to turbidity, alcohol content and color analyzes, over 10 days, in triplicate. The turbidity and color analyzes were performed daily. Analysis of alcohol content was performed at 2-day intervals.

\subsubsection{Turbidity}

The turbidity analysis was carried out by direct reading on a portable digital turbidimeter (Del Lab, model DLT-WV, São Paulo, Brazil), with a reading range between 0 and 1000 NTU (Nephelometric Turbidity Units), making dilutions necessary. The determination of the turbidity of the liqueur samples was performed according to Equation 4.

$T_{A}=T_{L} * F$

Where $\mathrm{T}_{\mathrm{A}}, \mathrm{T}_{\mathrm{L}}$ and $\mathrm{F}$ are related to the sample, reading turbidities and the dilution factor, respectively.

\subsubsection{Color}

The colorimetric parameters $\left(\mathrm{L}^{*}, \mathrm{a}^{*}\right.$ and $\left.\mathrm{b}^{*}\right)$ were determined in the liqueur samples. The parameters were determined by direct reading on a colorimeter (Konica Minolta, model Spectrophotometer CM-5, Tokyo, Japan), with D65 illuminant and $10^{\circ}$ observation angle.

The $\mathrm{L}^{*}$ parameter indicated the lightness of the sample, which varies from completely black to completely white, representing, respectively, the values 0 and 100 . The parameter $\mathrm{a}^{*}$ indicated the red saturation index, which varies from green $(-a)$ to red $(+a)$. The parameter $b^{*}$ indicated the yellow saturation index, which varies from blue (-b) to yellow (+ b) (Macedo et al., 2019).

The total color difference $(\Delta \mathrm{E})$, in relation to time zero, was calculated according to Equation 5 (Macedo et al., 2019).

$$
\Delta \mathrm{E}=\sqrt{\left(\mathrm{L}_{\mathrm{i}}^{*}-\mathrm{L}_{0}^{*}\right)^{2}+\left(\mathrm{a}_{\mathrm{i}}^{*}-\mathrm{a}_{0}^{*}\right)^{2}+\left(\mathrm{b}_{\mathrm{i}}^{*}-\mathrm{b}_{0}^{*}\right)^{2}}
$$

Where, $L_{0}^{*}, a_{0}^{*}, b_{0}^{*}, L_{i}^{*}, a_{i}^{*}$ e $b_{i}^{*}$ are related to the colorimetric parameters $L^{*}, a^{*}$ and $b^{*}$ at times zero and ith observation, respectively.

\subsubsection{Alcohol content}

To determine the alcohol content of the liqueurs, $50 \mathrm{~mL}$ samples were collected at 2-day intervals and subjected to distillation, with the aid of an alcohol microdistiller (Tecnal, TE-012, São Paulo, Brazil). After 
distillation, the sample was cooled to a temperature of $20{ }^{\circ} \mathrm{C}$ and the sample volume was replaced with distilled water. The relative density, at $20{ }^{\circ} \mathrm{C}$, of the distillate was calculated according to Equation 6 (Instituto Adolfo Lutz, 2008).

$\mathrm{D}_{20^{\circ} \mathrm{C}}=\frac{\mathrm{P}_{\text {sample- }} \mathrm{P}_{\text {pycnometer }}}{\mathrm{P}_{\text {water }-} \mathrm{P}_{\text {pycnometer }}}$

Where, $\mathrm{P}_{\text {sample }}, \mathrm{P}_{\text {pycnometer, }} \mathrm{P}_{\text {water }}$ are, respectively, the weights of the sample, the empty pycnometer and the water.

The conversion from relative density to alcoholic strength was carried out according to the correlation table established by Instituto Adolfo Lutz (2008).

\subsection{Statistical analysis}

The data were submitted to regression analysis and polynomial (linear, quadratic and cubic) and exponential (with 2 and 3 parameters) models were fitted to the data, with the aid of the software SigmaPlot 12.0 (SigmaPlot for Windows Version 12.0, Systat Software Inc., San Jose, CA, USA) and Statistica 10 (StatSoft, Inc., 2011). The mathematical model with the highest value of the adjusted determination coefficient $\left(\mathrm{R}^{2}\right.$ adj) (Equation 7) and lowest value of the Standard Error of the Regression (SER) (Equation 8) was chosen to represent the behavior of the data. The quality of the chosen model was verified according to the value of the determination coefficient $\left(\mathrm{R}^{2}\right)$ (Equation 9) (Macedo et al., 2020b).

$$
\begin{aligned}
& \mathrm{R}_{\text {adj }}^{2}=1-\frac{\sum_{\mathrm{i}=1}^{\mathrm{N}}\left(\mathrm{y}_{\text {exp }, \mathrm{i}}-\mathrm{y}_{\text {pred, }, \mathrm{i}}\right)^{2}}{\sum_{\mathrm{i}=1}^{\mathrm{N}}\left(\mathrm{y}_{\text {exp }, \mathrm{i}}-\overline{\mathrm{y}}\right)^{2}} \frac{\mathrm{N}-1}{\mathrm{~N}-\mathrm{p}} \\
& \mathrm{SE}=\sqrt{\left(\frac{\sum_{\mathrm{i}=1}^{\mathrm{N}}\left(\mathrm{y}_{\text {exp }, \mathrm{i}}-\mathrm{y}_{\text {pred }, \mathrm{i}}\right)^{2}}{\mathrm{~N}-\mathrm{p}}\right)} \\
& \mathrm{R}^{2}=1-\frac{\sum_{\mathrm{i}=1}^{\mathrm{N}}\left(\mathrm{y}_{\text {exp }, \mathrm{i}}-\mathrm{y}_{\text {pred, }} \mathrm{i}\right)^{2}}{\sum_{\mathrm{i}=1}^{\mathrm{N}}\left(\mathrm{y}_{\text {exp }, \mathrm{i}}-\overline{\mathrm{y}}\right)^{2}}
\end{aligned}
$$

Where, $\mathrm{y}_{\text {exp,i }}$ and $\mathrm{y}_{\text {pred,i }}$ are, respectively, experimental and predicted values of response for the ith observation; $\overline{\mathrm{y}}$ is the mean value of the experimental response; $\mathrm{N}$ is the number of observations; $p$ is the number of parameters in the model.

\section{Results and discussion}

\subsection{Turbidity}

Turbidity expresses the interference that suspended solids exert on the passage of light through the sample. The main solids responsible for liqueur turbidity are pectins, carbohydrates, and interaction between proteins and polyphenols. However, turbidity is closely associated with appearance, which, in turn, is one of the main quality parameters of a liqueur (Collado-Fernández et al., 2000; Nogueira \& Venturini Filho, 2005; Teixeira et al., 2011).

The dispersion of turbidity data, in NTU, of treatments over 10 days and their respective adjusted models are shown in Figure 2. 


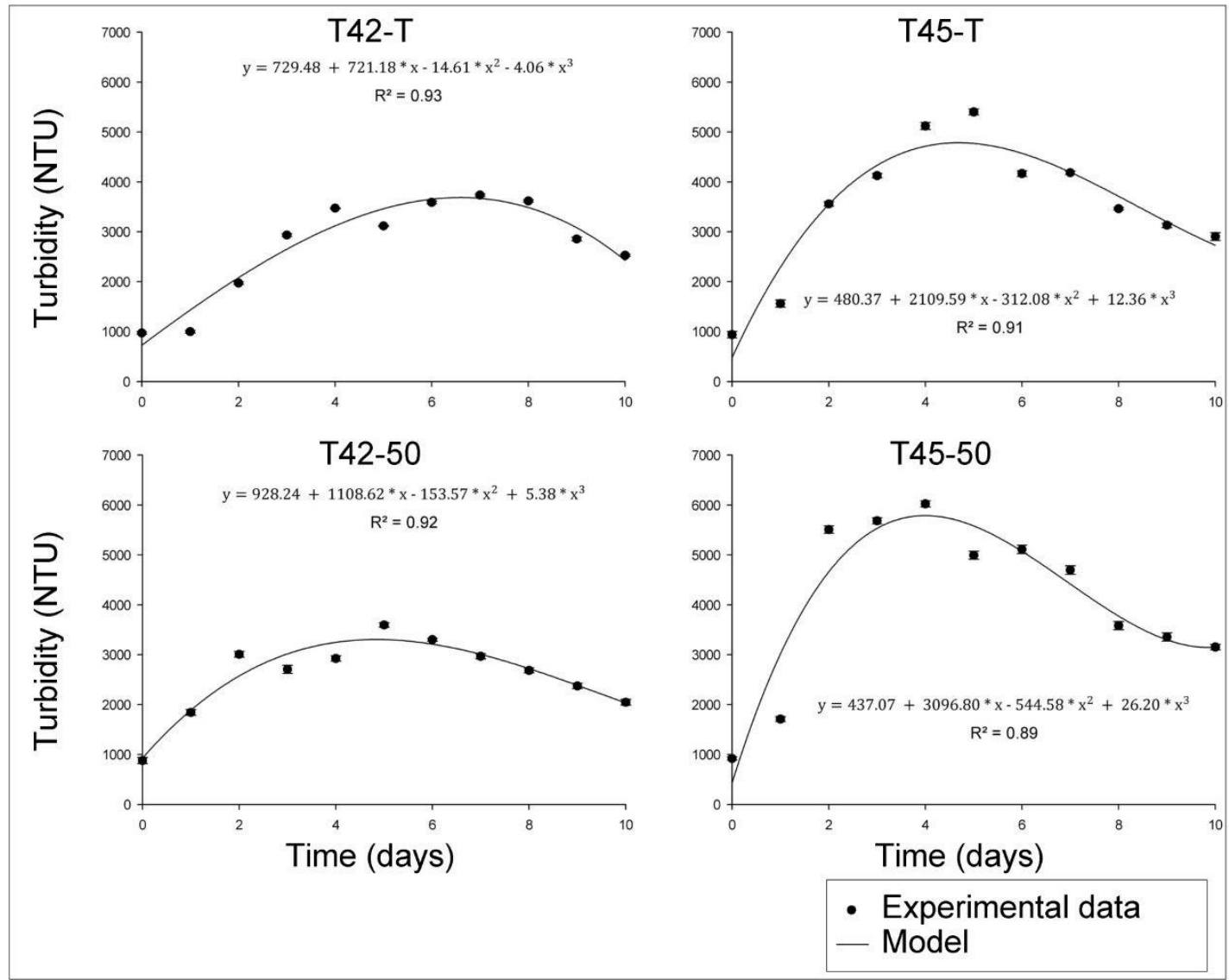

Figure 2. Turbidity of liqueurs over 10 days.

The four treatments showed an increase in turbidity in the first days, followed by a mild decline until the tenth day. The first days are characterized by the formation of clusters, resulting in higher turbidity. Subsequently, clusters tend to decant, reducing turbidity. According to mathematical models (Figure 2), the reduction in turbidity occurred after approximately 6.6, 4.7, 4.8 and 4.0 days for treatments T42-T, T45-T, T42-50 and T45-50, respectively.

Although the liqueurs had the same sugar concentration (30\%), the treatments using $45.0^{\circ}$ Brix Total Soluble Solids (TSS) of syrup concentration (T45-T and T45-50) showed the highest turbidity values over the days of maturity, with a final value of 2903.33 and 3153.33 NTU, respectively. Liqueurs made with $42.8{ }^{\circ}$ Brix syrup (T42-T and T42-50) presented 2526.67 and 2046.67 NTU, respectively, at the end of maturation.

The adjusted mathematical models showed good adjustment to the experimental data, with determination coefficient values of $0.93 ; 0.91 ; 0.92$ and 0.89 , for treatments T42-T, T45-T, T42-50 and T45-50, respectively. The models showed significant regression, at the level of $5 \%$ of significance, by the $\mathrm{F}$ test.

Quality liqueurs with higher sensory acceptance generally have low turbidity. For this, several clarification methods have been adopted to reduce the content of suspended solids. However, clarification results in a liquid that is poor in flavor and aroma (Baker \& Cameron, 1999; Nogueira \& Venturini Filho, 2005).

\subsection{Color}

As with turbidity, according to Penha (2004), color is one of the main factors responsible for the good appearance in liqueurs.

The total color difference, $\Delta \mathrm{E}$, of the treatments in relation to their respective colorimetric parameters at time zero and the mathematical models adjusted are shown in Figure 3. 


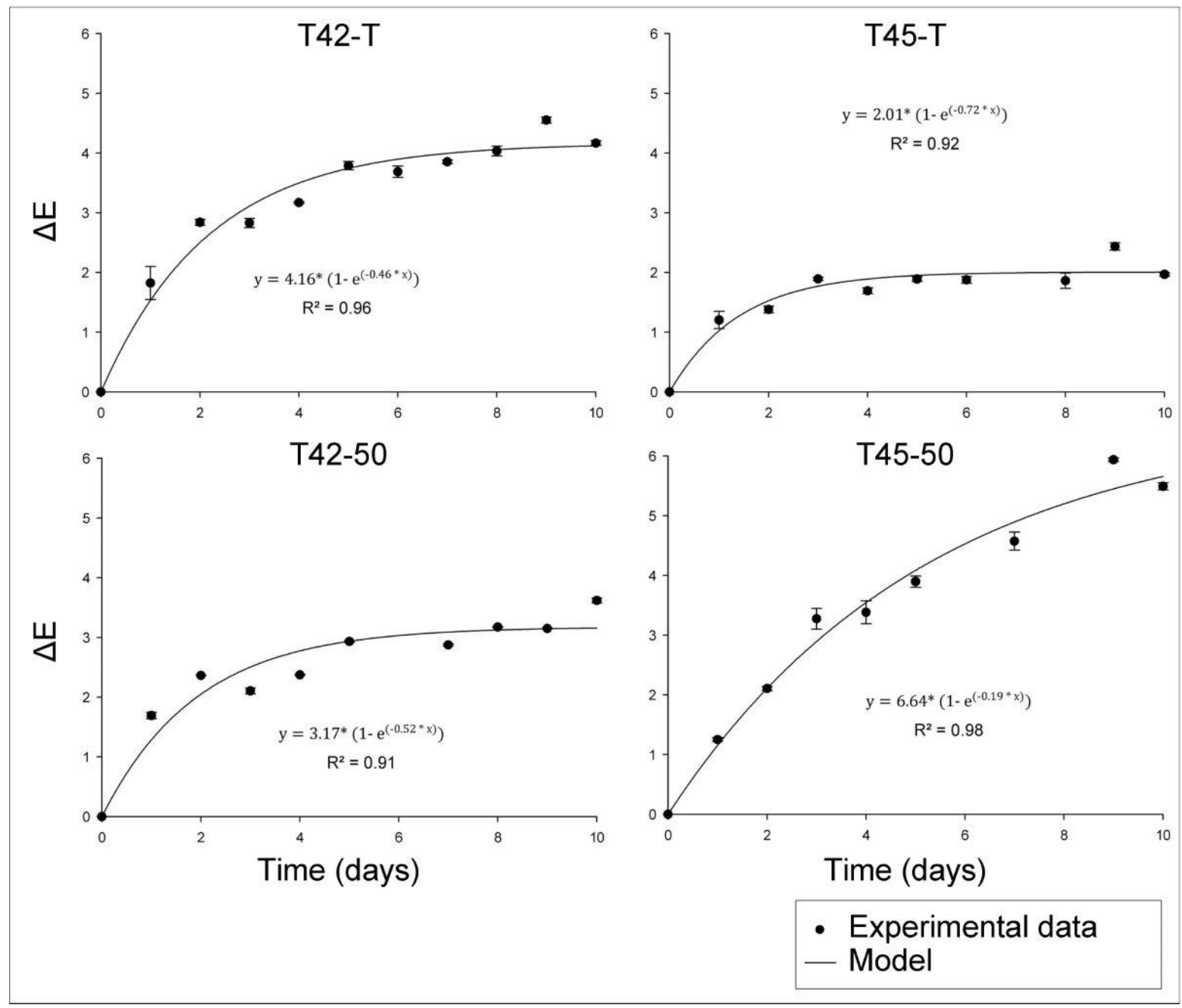

Figure 3. Total color difference of liqueurs over 10 days.

The $\Delta \mathrm{E}$ values obtained for treatments $\mathrm{T} 42-\mathrm{T}, \mathrm{T} 45-\mathrm{T}, \mathrm{T} 42-50$ and $\mathrm{T} 45-50$, at the end of the 10-day period, were, respectively, $4.17 ; 1.97 ; 3.62$ and 5.49. In liqueurs submitted to the tranchage process with respect to the treatments T42-T and T45-T, it could be seen that the highest concentration of syrup (T45-T) resulted in lower $\Delta \mathrm{E}$ values. In the treatments using the process of $70{ }^{\circ} \mathrm{C} / 20 \mathrm{~min}(\mathrm{~T} 42-50$ and $\mathrm{T} 45-50)$, the highest concentration (T45-50) resulted in higher $\Delta \mathrm{E}$ values. In the liqueurs made with the lowest concentration syrup, i.e., T42-T and T42-50, submitted to $50^{\circ} \mathrm{C}$ for 10 days (T42-50) resulted in $\Delta \mathrm{E}$ values slightly lower than the $\Delta \mathrm{E}$ values of the liqueur submitted to tranchage (T42-T). On the other hand, in liqueurs made with syrup of higher concentration (T45-T and T45-50), the liqueur submitted to the tranchage process (T45-T) presented lower $\Delta \mathrm{E}$ values when compared to the $\Delta \mathrm{E}$ values of the liqueur submitted to $50^{\circ} \mathrm{C}$ for 10 days (T45-50).

The color change can be seen with the naked eye when the $\Delta \mathrm{E}$ value is higher than 3 (Ramos \& Gomide, 2007; Mastromatteo et al., 2011). In this way, only the color change that occurred in the liqueur submitted to the T45-T treatment could not be perceived with the naked eye (delta $E=1,97$ ). The other treatments underwent noticeable color changes. However, these treatments showed a final $\Delta \mathrm{E}$ value close to 3 , indicating a subtle color change.

The $\Delta \mathrm{E}$ values, for the four treatments, showed a tendency towards a maximum value over the days. Thus, exponential models were adjusted to the data. The models showed significant regression, at the level of 5\% of significance, by the F test, in which the models of treatments T42-T, T45-T, T42-50 and T45-50 presented 
determination coefficients of, respectively, 0.96; 0.92; 0.91 and 0.98 , therefore being capable of representing the behavior of the $\Delta \mathrm{E}$ values over time.

\subsection{Alcohol content}

The alcohol levels of each treatment over the maturation time were statistically equal according to the confidence interval, at the $95 \%$ confidence level, as shown in Figure 4.
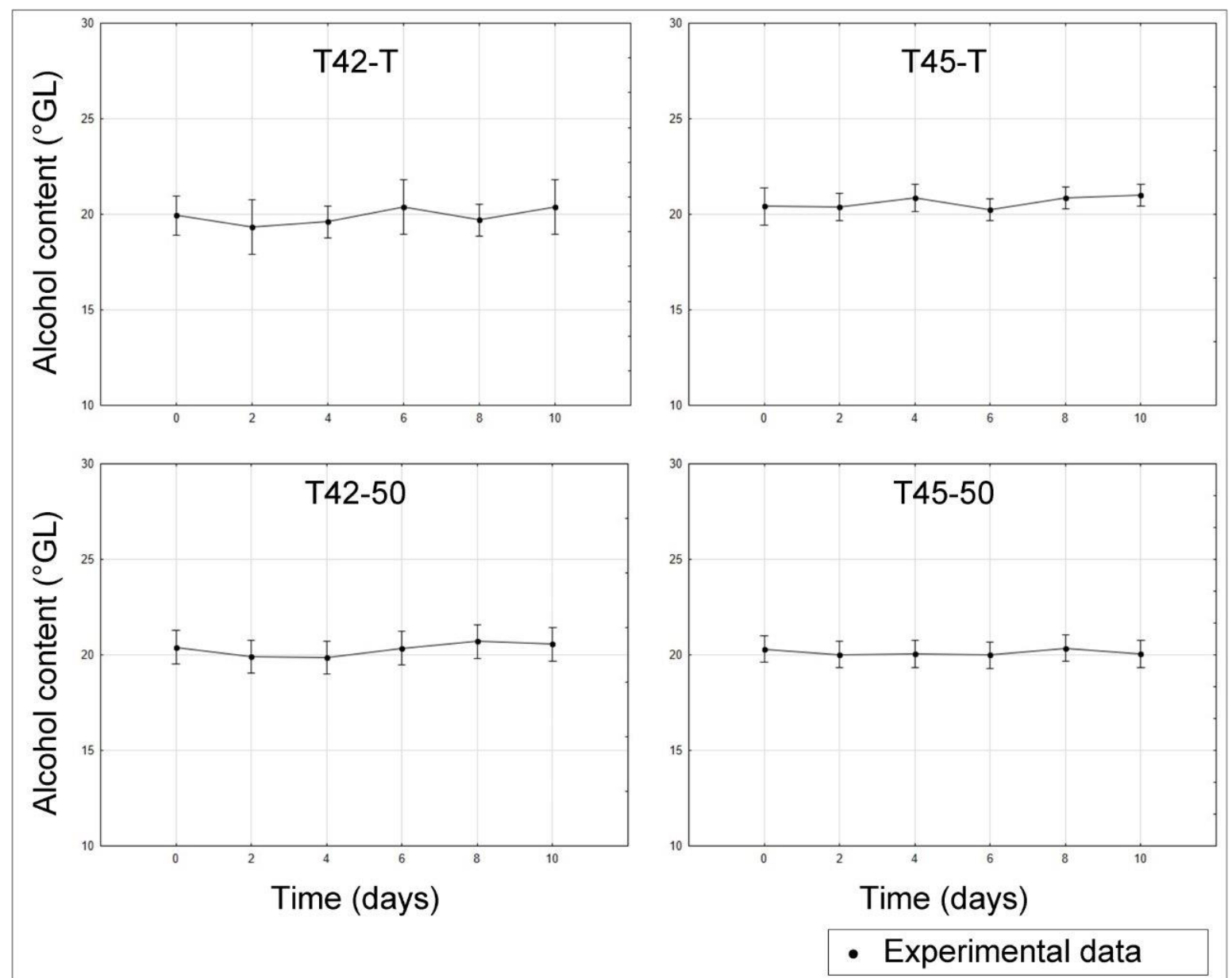

Figure 4. Alcohol content of liqueurs over 10 days.

The alcohol levels of the liqueurs immediately after applying the treatments T42-T, T45-T, T42-50 and T45-50, were, respectively, $19.95 \pm 0.97 ; 20.41 \pm 0.95 ; 20.40 \pm 0.94$ and $20.31 \pm 0.68^{\circ} \mathrm{GL}$.

Over the ten days of maturation, the alcohol levels were within the value established by Brazilian legislation, from $15 \%$ to $54 \%(\mathrm{v} / \mathrm{v})$ (Brasil, 2009). Commercial liqueurs generally have an alcohol content between 18 and $30^{\circ} \mathrm{GL}$ (Teixeira et al., 2007). The treatments T42-T, T45-T, T42-50 and T45-50 showed an average alcohol content of 19.87, 20.79; 20.30 and 20.13\%. Teixeira et al. (2007) evaluated the sensorial acceptance of banana liqueur with an alcohol content of $18 \%$ and $24 \%$, in which the liqueur with a lower alcohol content showed higher acceptance. The same was observed by Hashizume et al. (1976) when evaluating the sensorial acceptance of passion fruit liqueur with alcohol strength of 21,23 and $25^{\circ} \mathrm{GL}$, found that the highest content was less accepted than the two lower ones and the levels of 21 and $23^{\circ} \mathrm{GL}$ showed equal acceptance. 
Oliveira et al. (2015) evaluated the alcohol content of soursop liqueur over 240 days, kept at room temperature, with a significant reduction in alcohol content over the days, reaching, after 60 days, lower values than established by law. However, the authors attributed this reduction to the polyethylene packaging used, which allows gas exchange between the liqueur and the environment. In the present work, amber glass bottles were used, minimizing the volatilization of alcohol over time.

\section{Conclusion}

The treatment using the lowest concentration syrup and at $50{ }^{\circ} \mathrm{C}$ for 10 days (T42-50) showed the lowest turbidity value at the end of the 10 days of maturation.

The treatment using the highest syrup concentration and submitted to the tranchage process (T45-T) showed the smallest total color difference at the end of the 10 days of maturation, in relation to the color of the liqueur at time zero. This difference was less than the minimum value perceptible to the naked eye.

The alcohol levels of the liqueurs were statistically equal to each other at time zero. In addition, for all treatments, the levels did not change significantly over the 10 days.

\section{Acknowledgements}

Fundação de Amparo à Pesquisa e Inovação do Espírito Santo (FAPES) for the Capixaba researcher scholarships to the fifth and sixth authors. This work was carried out with the support of the Coordenação de Aperfeiçoamento de Pessoal de Nivel Superior - Brasil (CAPES).

\section{References}

Almeida Paula, H. A., Abranches, M. V., \& de Luces Fortes Ferreira, C. L. (2015). Yacon (Smallanthus Sonchifolius): A food with multiple functions. Critical Reviews in Food Science and Nutrition, 55(1), 32-40. PMid:24915403.

http://dx.doi.org/10.1080/10408398.2011.645259

Almeida, E. L., Lima, L. C., Borges, V. T. N., Martins, R. N., \& Batalini, C. (2012). Elaboração de licor de casca de tangerina (Citrus reticulata Blanco), variedade ponkan, com diferentes concentrações de casca e tempos de processamento. Alimentos e Nutrição, 23(2), 259-265.

Baker, R. A., \& Cameron, R. G. (1999). Clouds of citrus juices and juice drinks. Food Technology, 53(1), 64-69.

Barros, J. C., dos Santos, P. A., Isepon, J. S., Silva, J. W., \& Silva, M. A. P. (2008). Obtenção de licor de leite a partir de diferentes fontes alcoólicas. Global Science and Technology, 1(4), 27-33.

Bragança, M. G. L. (2013). Licor processamento artesanal. Belo Horizonte: EMATER-MG.

Brasil. (2009, junho 4). Regulamenta a Lei no 8.918, de 14 de julho de 1994, que dispõe sobre a padronização, a classificação, o registro, a inspeção, a produção e a fiscalização de bebidas (Decreto n. 6871, de 4 de junho de 2009). Diário Oficial [da] República Federativa do Brasil, Brasília. Retrieved in 2019, March 15, from http://www.planalto.gov.br/ccivil_03/_ato20072010/2009/decreto/d6871.htm

Caetano, B. F. R., Moura, N. A., Almeida, A. P. S., Dias, M. C., Sivieri, K., \& Barbisan, L. F. (2016). Yacon (Smallanthus sonchifolius) as a food supplement: Health-promoting benefits of fructooligosaccharides. Nutrients, 8(7), 436. PMid:27455312. http://dx.doi.org/10.3390/nu8070436

Collado-Fernández, M., González-Sanjosé, M. L., \& Pino-Navarro, R. (2000). Evaluation of turbidity: Correlation between Kerstez turbidimeter and nephelometric turbidimeter. Food Chemistry, 71(4), 563-566. http://dx.doi.org/10.1016/S03088146(00)00212-0

Contado, E. W. N. F., Rocha, D. A., Queiroz, E. R., Abreu, C. M. P., \& Ramos, E. M. (2015). Emprego da farinha e do extrato de frutanos de yacon na elaboração de apresuntados. Brazilian Journal of Food Technology, 18(1), 49-56.

http://dx.doi.org/10.1590/1981-6723.3814

Food and Agriculture Organization of the United Nations - FAO. (2019). FoodData Central. Rome: FAOSTAT. Retrieved in 2020, February 7, from https://fdc.nal.usda.gov/fdc-app.html\#/food-details/173944/nutrients

Hashizume, T., Cuoco, A. C., Miya, E. E., \& Draetta, I. S. (1976). Processamento do licor de maracujá. Boletim do Instituto de Tecnologia de Alimentos, 48, 97-116.

Instituto Adolfo Lutz - IAL. (2008). Métodos físico-quimicos para análise de alimentos (4. ed). São Paulo: IAL.

Ma, Y., Qiao, H., Wang, W., Chen, T., Du, X., Zhai, X., \& Zhang, S. (2014). Variations in Physicochemical Properties of Chinese Fenjiu During Storage and High-Gravity Technology of Liquor Aging. International Journal of Food Properties, 17(4), 923-936. http://dx.doi.org/10.1080/10942912.2012.678536 
Macedo, L. L., Silva Araújo, C., Vimercati, W. C., Saraiva, S. H., \& Teixeira, L. J. Q. (2019). Evaluation of different bleaching methods applied to yacon. Journal of Food Process Engineering, 42(7), http://dx.doi.org/10.1111/jfpe.13276

Macedo, L. L., Vimercati, W. C., \& Araújo, C. S. (2020a). Fruto-oligossacarídeos: Aspectos nutricionais, tecnológicos e sensoriais. Brazilian Journal of Food Technology, 23, e2019080. http://dx.doi.org/10.1590/1981-6723.08019

Macedo, L. L., Vimercati, W. C., Araújo, C., Saraiva, S. H., \& Teixeira, L. J. Q. (2020b). Effect of drying air temperature on drying kinetics and physicochemical characteristics of dried banana. Journal of Food Process Engineering, 43(9), 1-10. http://dx.doi.org/10.1111/jppe.13451

Mastromatteo, M., Incoronato, A. L., Conte, A., \& Del Nobile, M. A. (2011). Shelf life of reduced pork back-fat content sausages as affected by antimicrobial compounds and modified atmosphere packaging. International Journal of Food Microbiology, 150(1), 1-7. PMid:21820750. http://dx.doi.org/10.1016/j.ijfoodmicro.2011.07.009

Moreira Junior, S., Freitas, M. L. F., Martins, M. L., Benevenuto, W. C. A. N., Gonçalves, I. F., \& Martins, A. D. (2018). Avaliação do efeito de yacon em kefir sabor morango. Revista do Instituto de Latícinios Cândido Tostes, 73(2), 51-61.

http://dx.doi.org/10.14295/2238-6416.v73i2.630

Nogueira, A. M. P., \& Venturini Filho, W. G. (2005). Ultra e microfiltração de licor de acerola. Brazilian Journal of Food Technology, 8, 305-311.

Oliveira, E. N. A., \& Santos, D. C. (2011). Processamento e avaliação da qualidade de licor de açaí (Euterpe oleracea Mart. ). Revista do Instituto Adolfo Lutz, 70(4), 534-541.

Oliveira, E. N. A., Santos, D. C., Gomes, J. P., Rocha, A. P. T., \& Albuquerque, E. M. B. (2015). Estabilidade física e química de licores de graviola durante o armazenamento em condições ambientais. Revista Brasileira de Engenharia Agrícola e Ambiental, 19(3), 245-251. http://dx.doi.org/10.1590/1807-1929/agriambi.v19n3p245-251

Padilha, V. M., Rolim, P. M., Salgado, S. M., Livera, A. S., Alvachian, S., Andrade, C., \& Guerra, N. B. (2010). Sensorial profile of chocolate cakes formulated with yacon flour (Smallanthus sonchifolius). Food Science and Technology, 30(3), 735-740. http://dx.doi.org/10.1590/S0101-20612010000300026

Passos, F. R., Cruz, R. G., Santos, M. V., \& Fernandes, R. V. B. (2013). Avaliação físico-química e sensorial de licores mistos de cenoura com laranja e com maracujá. Revista Brasileira de Produtos Agroindustriais, 15(3), 211-218. http://dx.doi.org/10.15871/1517-8595/rbpa.v15n3p211-218

Penha, E. M. (2004). Manual para fabricação artesanal de licor de acerola (1. ed., 17 p.) Rio de Janeiro: Embrapa Agroindústria de Alimentos

Programa Brasileiro para a Modernização da Horticultura \& Produção Integrada de Frutas - PBMH \& PIF. (2006). Normas de Classificação de Banana. São Paulo: CEAGESP.

Ramos, E. M., \& Gomide, L. A. M. (2007). Avaliação da qualidade de carnes: Fundamentos e metodologias. Viçosa: UFV. Reventos, P. (1971). El licorista en casa. Barcelona: Editora SINTES.

Rocha, L. S., Silva, R., \& Silva, E. M. M. (2015). Use of yacon in natura and its flour in the development of diet and conventional cakes. Bioscience Journal, 31(6), 1738-1749. http://dx.doi.org/10.14393/BJ-v31n6a2015-29928

StatSoft, Inc. (2011). STATISTICA (data analysis software system), version 10. Retrieved in 2020, February 7 , from www.statsoft.com

Teixeira, L. J. Q., Ramos, A. M., Chaves, J. B. P., \& Stringheta, P. C. (2007). Testes de aceitabilidade de licores de banana. Revista Brasileira de Agrociências, 13(2), 205-209.

Teixeira, L. J. Q., Ramos, A. M., Chaves, J. B. P., Silva, P. H. A., \& Stringheta, P. C. (2005). Avaliação tecnológica da extração alcoólica no processamento de licor de banana. Boletim do Centro de Pesquisa e Processamento de Alimentos, 23(2), 329346. http://dx.doi.org/10.5380/cep.v23i2.4482

Teixeira, L. J. Q., Simões, L. S., Rocha, C. T., Saraiva, S. H., \& Junqueira, M. S. (2011). Tecnologia, composição e processamento de licores. Enciclopédia Biosfera, 7, 1-17.

Teixeira, L. J. Q., Simões, L. S., Saraiva, S. H., Junqueira, M. S., \& Sartori, M. A. (2012). Determinação da proporção de açúcar e fruta necessários para conferir os atributos ideiais ao licor de abacaxi. Enciclopédia Biosfera, 8(14), 1883-1889.

Viera, V. B., Rodrigues, J. B., Cristina, C., Brasil, B., \& Severo, C. (2010). Produção, caracterização e aceitabilidade de licor de camu-camu (Myrciaria dúbia (H.B.K.) Mcvaugh). Alimentos e Nutrição, 21(4), 519-522.

Funding: Fundação de Amparo à Pesquisa e Inovação do Espírito Santo (FAPES) and the Coordination for Coordenação de Aperfeiçoamento de Pessoal de Nível Superior - Brasil (CAPES). 